\title{
ASSESSMENT OF INSECTICIDAL POTENCY OF EGGSHELL POWDER AGAINST MAIZE WEEVIL
}

\section{Olagunju O.D ${ }^{1^{*}}$., Rahman M.O ${ }^{1}$., Okparavero N.F ${ }^{1}$, Abah I.A ${ }^{1}$., Odutola B.S ${ }^{1}$, Adarabierin I.G ${ }^{2}$., Abel G.I ${ }^{1}$., Aina O.B ${ }^{3}$., Babatunde $\mathrm{O}^{3}$ and Haruna P.B.}

${ }^{1}$ Durable Crops Research Department, Nigerian Stored Products Research Institute (NSPRI) Ilorin. Kwara State.

${ }^{2}$ Perishable Crops Research Department, Nigerian Stored Products Research Institute

(NSPRI) Ilorin. Kwara State.

${ }^{3}$ Research Outreach Department, Nigerian Stored Products Research Institute (NSPRI) Ilorin. Kwara State.

*Correspondence: oluwaseundot10@yahoo.com Phone +2347069065378

Cite this article:

Olagunju O.D., Rahman M.O., Okparavero N.F., Abah I.A., Odutola B.S., Adarabierin I.G., Abel G.I., Aina O.B., Babatunde O., Haruna P.B. (2021), Assessment of Insecticidal Potency of Eggshell Powder Against Maize Weevil. African Journal of Agriculture and Food Science 4(3), 41-50. DOI: 10.52589/AJAFS-S2EKIFZU.

\section{Manuscript History}

Received: 12 July 2021

Accepted: 24 Aug 2021

Published: 5 Sept 2021

Copyright $\odot 2020$ The Author(s). This is an Open Access article distributed under the terms of Creative Commons AttributionNonCommercial-NoDerivatives 4.0 International (CC BY-NC-ND 4.0 ), which permits anyone to share, use, reproduce and redistribute in any medium, provided the original author and source are credited.
ABSTRACT: Efficacy of chicken eggshell powder at concentrations $0,0.25,0.5,1.0$ and $2.0 \mathrm{~g} / 100 \mathrm{~g}$ maize, for control of Sitophilus zeamais, were compared with permethrin at dosage rate of $0.167 \mathrm{~g} / 100 \mathrm{~g}$ of yellow maize. Experiments were conducted at Biotechnology laboratory (NSPRI), Ilorin under ambient condition $\left(26 \pm 3^{\circ} \mathrm{C} 65 \pm 5 \% \mathrm{RH}\right)$. Mortality of $\mathrm{S}$. zeamais increased with increasing dosages of the CESP as well as with days of exposure. CESP at $2.0 \mathrm{~g}$ gives $96.67 \%$ mortality which is not significantly different from the positive control. The mean progeny emergence $(0.00 \%)$, weight loss $(1.11 \%)$, and percentage grain damage $(19.68 \%)$ by $S$. zeamais was significantly $(P \leq 0.05)$ decreased with increased dosage of CESP. However, CESP did not significantly affect seed germination. Total coliform count at $2.0 \mathrm{~g}\left(2.48 \times 10^{2}\right)$ was significantly different from both positive and negative controls at $p<0.05$ Therefore, CESP can serve as a good maize protectant which can be used as substitute for synthetic chemicals.

KEYWORDS: Chicken eggshell powder (CESP), Permethrin, Sitophilus zeamais, Total Coliform 


\section{INTRODUCTION}

Maize plant (Zea mays) is one of the oldest and the mostly cultivated world cereals. It belongs to the family Graminae and is one of the most important cereal crops in Nigeria. After wheat and rice, maize is the third most grown cereal (Lyon, 2000). The grain is utilized for human consumption and forms about 50\% of livestock feeds (Longe, 2010). The grain is very nutritious, with about $70 \%$ carbohydrate, $4-5 \%$ fats and oils and 9.5 (Larger and Hills, 2001). It is an important source of protein ranking only after meat, fish and legumes in term of annual protein production. It also rich in vitamins and fats which makes the crop compare favorably as an energy source, with root and tuber crops per unit quantity (Dasbak et al; 2008). In developing world, about $50 \%$ of all maize is consumed by humans as food while $43 \%$ is fed to livestock and the remainder for industrial purposes (IITA, 2003). Though maize grain can be stored for a considerable period of time, preservation of quality during long term storage is a problem in many parts of the world (Gras et al; 2000). Degradation of grain quality is recorded as rodent and insect infestation, cracking of seeds due to over-drying, and contamination with mycotoxins caused by molds and bacteria (Boxall, 2001).

The maize weevil (Sitophilus zeamais Motschulsky) is a major pest of stored maize grains and its infestation causes severe postharvest losses of staple food crops in Nigeria (Oni and Ileke, 2008). Presence of the insects in the grain lowers its quality and value. It also brings about the establishment of mold infestations including Aspergillus spp. which produces aflatoxins making the grain unsuitable for food and feed (Kling, 2001). The destructive activities of this insect and other storage pests have been widely subdued by chemical control methods, such as fumigation of stored products with carbon disulphide and phosphine and dusting with pirimiphos methyl or permethrin (Adedire et al., 2011). The problems of many synthetic insecticides however include high persistence in the soil after use, environmental pollution, high cost of application, and lethal effects on non-target organisms or directly toxic to users (Ofuya and Longe, 2009). There has been a steady increase however in recent times, in the use of naturally (plant and animal materials) available products as a cheaper and ecological safer means of controlling insect pests of stored grains, especially in the tropics with medicinal properties as grain protectants (Longe, 2010)

Chicken eggshell which form the outer crust of an egg is a non-edible product with limited use and value and is largely disposed as waste. It is necessary to find an alternative means which would transform the waste giving financial benefits to the egg processing company and also help to overcome the high disposal costs and environmental concerns (MacNeil, 2006) and serve as an alternative to synthetic chemicals. This study aims at evaluating the efficacy of chicken eggshell powder in controlling $S$. zeamais on maize grains and to assess the effect of the eggshell powder on adult mortality, seed damage, weight loss, and germination microbial load and progeny developments of the insects (S. zeamais).

\section{Materials}

\section{Experimental site}

The experiment was carried out in the Biotechnology laboratory of Nigerian Stored Products Research Institute (NSPRI), Ilorin, Kwara State. 


\section{Insect culture}

Adults of S. zeamais was obtained from already existing culture in the Entomology laboratory of Nigerian Stored Product Research Institute, Ilorin, Kwara state Nigeria and was mass reared on yellow maize grains purchased from Ago-market in 1litre kilner jars covered with muslin cloth to serve as source of aeration and to prevent escape of the insects at temperature of $26 \pm 3{ }^{\circ} \mathrm{C}$ and $65 \pm 5 \%$ relative humidity. The adult $S$. zeamais was sieved out after 14 days and the kilner jar was left undisturbed in the insectary. Newly emerged three days old insects were used for the bioassay (Odeyemi et al., 2008).

\section{Collection and preparation of grains}

The purchased maize was sorted to separate the damaged grains from the wholesome grains and cold shocked for 14 days to ensure infestation free and were brought out thereafter to be equilibrated under atmospheric condition on the laboratory table before usage.

\section{Preparation of eggshell powder}

The eggshell used for this experiment was gathered from chicken eggs consumed at home. It was washed thoroughly under running water, blanched and air dried in the laboratory until crispy dried, it was grounded into powder with electric blender (LAPRIVA MODEL NO:LAT4PN) and sieved 90 microns mesh size sieve to obtain fine powder. The powder was stored in an air tight container prior to use.

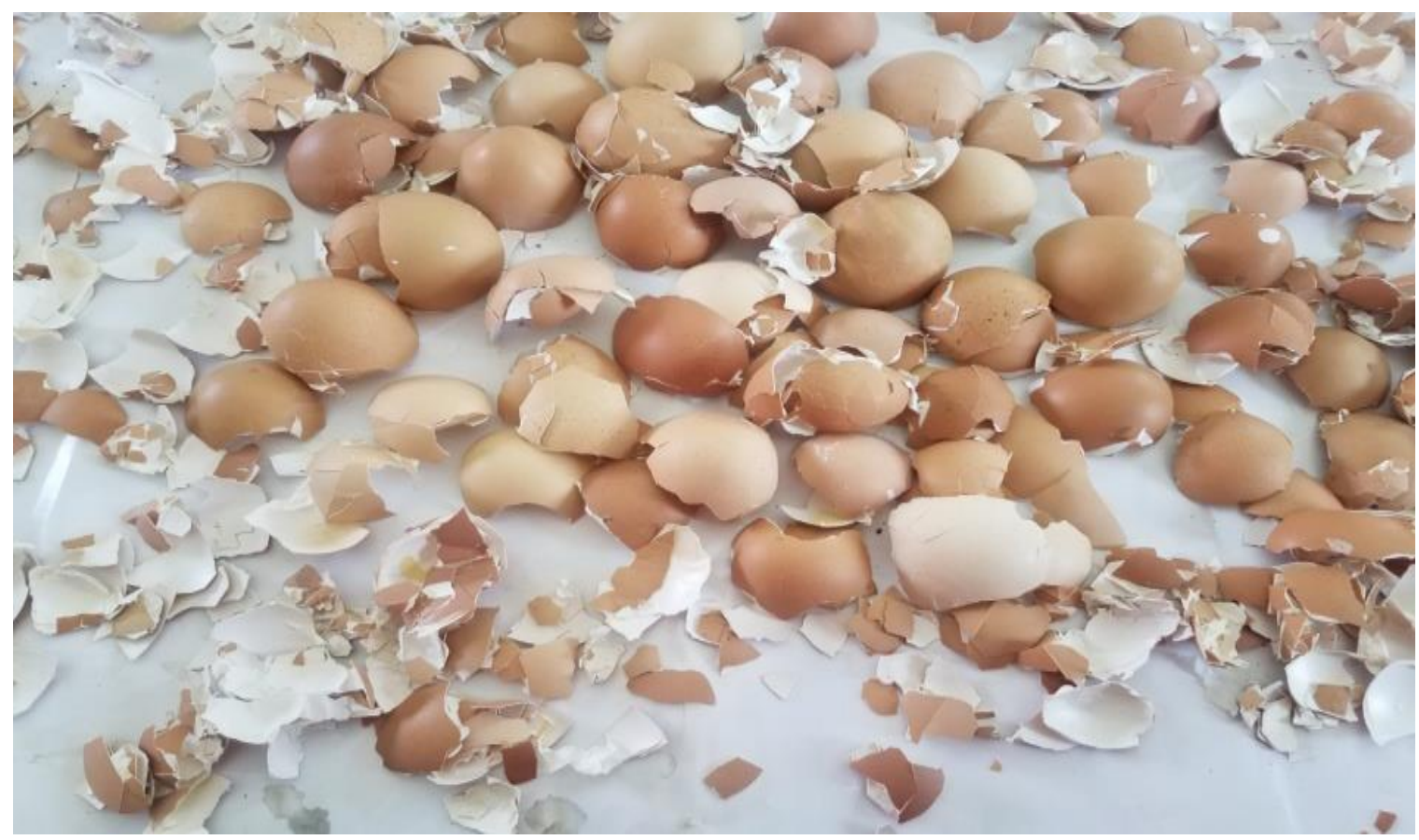

Plate 1: Chicken eggshell 


\section{Description of experimental set-up}

Different dosages $(0.25,0.5,1.0$ and $2.0 \mathrm{~g})$ of the eggshell powder were weighed and was admixed separately to $100 \mathrm{~g}$ of wholesome maize in $360 \mathrm{ml}$ cylindrical gas jars container and $100 \mathrm{~g}$ of another maize was weighed and admixed with permethrin $0.6 \%$ a.i $\left(\mathrm{Rambo}^{\mathrm{TM}}\right)$ at dose rate of $0.167 \mathrm{~g} / 100 \mathrm{~g}$ of maize for positive control and another lot of $100 \mathrm{~g}$ of maize that was not treated was placed in $360 \mathrm{ml}$ jar for negative control. The containers with their contents (Maize and treatment) were gently shaken for 5 minute to ensure thorough coating of maize grains.

Ten 3-day old mixed sexed $S$. zeamais were introduced into containers containing treated maize and control and was covered with muslin cloth to allow aeration and prevent escape of insect. Three replicate of the treatment and controls (positive and negative) were laid out in completely randomized design (CRD) on the laboratory table. Adult mortality was assessed after 7 and 14 days of infestation. Dead insect was removed and live ones retained. The insect was confirmed dead when there was no response to probing with sharp pin at abdomen (Adedire et al., 2011).The insects in the containers were sieved out at 14 days and the vials were closed and left undisturbed for 26 days (40 days of post treatment) and newly emerged adult insects were counted and the maize seeds were reweighed, the percentage loss in weight was determined and recorded using the method described by Odeyemi and Daramola (2000).

$\%$ Weight loss $=\underline{\text { Initial weight }- \text { final weight }} \times 100$ Initial weight

After re-weighing, the number of damaged grains were evaluated by counting wholesome and seed with weevil emergent holes. Percentage seed damaged was also calculated according to

The percentage seed damaged were also evaluated as follows:

$\%$ seed damage $=$ Number of seeds damaged $\times 100$

Total no of seeds

The percentage insect mortality was calculated according to Niber, (1994) as

Mortality $\%=\underline{\text { Number of dead insect }} \times 100$

Total number of insect

\section{Viability Assessment}

Initial and final (40-day post treatment) seed germination was determined. 10 grains were randomly picked from each sub-sample per treatment after F1 progeny count. The seeds were placed on moistened cotton wool in $9 \mathrm{~cm}$ diameter disposable Petri dish which was humidified every 3 days. Germination count was taken on the $10^{\text {th }}$ days (Rao et al., 2006). Percentage seed germination was calculated using previously described method (Adedire and Akinkurolere 2005)

$$
\text { Germination }(\%)=\frac{\text { Number of germinated seeds }}{\text { Total number of seed planted }} \times 100
$$




\section{Microbial Analysis}

Microbiological analysis was done using pour plate method described by Society for General Microbiology (SGM, 2006)

\section{Statistical Analysis}

Data were subjected to analysis of variance (ANOVA) and where significant differences existed, treatment means were compared at 0.05 significant level using the New Duncan's Multiple Range Test (Zar, 1984).

\section{RESULTS}

Table 1: Effect of the eggshell powder on mortality, protection, Reproductive parameters of Sitophilus zeamais, and germinability of maize seed

\begin{tabular}{|c|c|c|c|c|c|c|c|}
\hline $\begin{array}{l}\text { Treat } \\
\text { ment }\end{array}$ & $\begin{array}{c}\text { Dosage } \\
\mathrm{g} \\
/ 100 \mathrm{~g}\end{array}$ & $\begin{array}{c}\text { \% Mortality } \\
7\end{array}$ & 14 & $\begin{array}{l}\text { Percentage } \\
\text { grain damage }\end{array}$ & $\begin{array}{l}\text { Percentage } \\
\text { weight loss }\end{array}$ & $\begin{array}{c}\mathrm{F} 1 \\
\text { Emergence }\end{array}$ & Germination \\
\hline \multirow[t]{2}{*}{$\mathrm{Co}$} & & $14.44 \pm 6.26^{\mathrm{a}}$ & $24.44 \pm 8.18^{\mathrm{a}}$ & $73.33 \pm 16.11^{b}$ & $4.44 \pm 5.27^{\mathrm{ab}}$ & $0.88 \pm 1.05^{\mathrm{b}}$ & $70.00 \pm 20.62^{a}$ \\
\hline & 0.25 & $58.89 \pm 30.59^{b}$ & $80.00 \pm 37.08^{b}$ & $43.52 \pm 12$ & $2.22 \pm 4.41^{\mathrm{ab}}$ & $0.00 \pm 0.000^{\mathrm{a}}$ & $65.56 \pm 26.03^{a}$ \\
\hline \multirow[t]{3}{*}{ E.G.S } & 0.5 & $86.67 \pm 16.58^{c}$ & $92.22 \pm 13.02^{b}$ & $52.32 \pm 11.10^{\mathrm{ab}}$ & $3.33 \pm 5.00^{\mathrm{ab}}$ & $0.00 \pm 0.000^{\mathrm{a}}$ & $65.56 \pm 30.05^{a}$ \\
\hline & 1.0 & $95.56 \pm 8.82^{c}$ & $95.56 \pm 7.26^{b}$ & $41.19 \pm 13.81^{\mathrm{ab}}$ & $3.33 \pm 7.07^{\mathrm{ab}}$ & $0.00 \pm 0.000^{\mathrm{a}}$ & $72.22 \pm 29.91^{\mathrm{a}}$ \\
\hline & 2.0 & $96.67 \pm 7.07^{\mathrm{c}}$ & $96.67 \pm 5.00^{\mathrm{b}}$ & $19.68 \pm 8.21^{\mathrm{a}}$ & $1.11 \pm 3.33^{\mathrm{a}}$ & $0.00 \pm 0.000^{\mathrm{a}}$ & $75.56 \pm 26.98^{a}$ \\
\hline RAM & 0.167 & $96.67 \pm 5.00^{c}$ & $98.89 \pm 3.33^{b}$ & $38.78 \pm 7.05^{\mathrm{ab}}$ & $7.78 \pm 6.67^{b}$ & $0.11 \pm 0.333^{\mathrm{a}}$ & $53.33 \pm 25.50^{\mathrm{a}}$ \\
\hline
\end{tabular}

Each value is a mean \pm standard error of three replicates. Mean followed by the same letter in a column are not significantly different $(\mathrm{P}<0.05)$ from each other using new Duncan multiple range test.

Co- Control, E.G.S - Eggshell powder, RAM-Rambo powder,

DAT-Days after treatment

\section{Effect of the Chicken eggshell powders on the mortality of adult S.zeamais}

Table 1 shows the percentage mortality count of adult $S$. zeamais exposed to the different concentrations of the chicken (Gallus gallus) eggshell powder The different concentrations of the test plants exhibited varying degrees of insecticidal activities killing adult $S$. zeamais more than the control $(\mathrm{p}<0.05)$. There were significant differences in the mortalities of $S$. zeamais with treated experiment compared to the untreated control.

There was no significant difference (0.05) in maize weevil mortality at $0.5,1.0,2.0 \mathrm{~g} / 100 \mathrm{~g}$ of maize grain and the positive control $\left(\mathrm{Rambo}^{\mathrm{TM}}\right.$ at dose rate $0.167 \mathrm{~g} / 100 \mathrm{~g}$ of maize) but are significantly different from the maize treated with $0.25 \mathrm{~g} / 100 \mathrm{~g}$ of maize $(58.89 \%$,) and 
untreated control at 7 DAT. At 14 DAT there were significant differences in mortalities of $S$. zeamais with treated compared to untreated control. The chicken eggshell powders tested at various level showed the various bioactivity against Sitophilus zeamais and significantly (P $<0.05)$ reduce longevity of adult on treated maize grains. All the dosages of the powders showed weevil mortality ranging from 58.89 to $95.56 \%$ and 80.00 to $96.67 \%$ at 7 and 14 days after treatment respectively. Adult mortality increased as the dosages increases. The chicken eggshell powder was most effectives against $S$. zeamais at dosage level of 2.0 evoking $96.67 \%$ mortality, after 7 and 14 days of exposure. This followed by dosage level of 1.0, 0.5 and 0.25 with mortality of $95.56 \%, 86.67 \%, 58.89 \%$ and $95.56 \%, 92.22 \%$ and 80.00 at 7 and 14 days after treatment respectively.

\section{Progeny Development}

The various dosages of the eggshell powder significantly $(\mathrm{P}<0.05)$ reduced the progeny of $S$. zeamais. All dosages significantly prevent the emergence $(0.00 \%)$ of $S$. zeamais compared to the control $(0.88 \%)$ and positive control $(0.11 \%)$. The percentage adult emergence in the untreated maize seeds was significantly different $(\mathrm{P}<0.05)$ from emergence in the treated maize. The eggshell powder completely inhibited the development of $S$. zeamais.

\section{Damage Assessment}

Maize seeds treated with chicken eggshell powder showed significant difference $(\mathrm{P}<0.05)$ in reduction of damage caused by $S$. zeamais. Compared to untreated control of highest damage of $(73.33 \%)$ damage occurred as revealed by the emergent holes.

\section{Weight Loss Assessment}

Maize treated with $2.0 \mathrm{~g}$ of the powder significantly reduced the weight loss compared to the control and positive control but there was no significant difference between dosage $0.25,0.5$ 1.0 and control.

\section{Viability Assessment}

The effect of chicken eggshell powder on the viability of treated grains showed that none of the dosage level of the powder used adversely affected the viability of the maize grains when compared with the untreated control and the positive control after 1 months of storage (Table $3)$. Almost all the treated seeds germinated. There was no significantly different $t(P>0.05)$ in the mean percentage viability of control (untreated), positive control and the seed treated at four dosage levels of the chicken egg powder.

The high mortality of adult mortalities observed on maize treated with chicken eggshell powder could be due to the toxic effect of the product on $S$. zeamais. The analysis of the result showed that chicken eggshell powder at the tested dosages is good in managing $S$. zeamais in storage. In all dosages, Chicken eggshell powder at $2.0 \mathrm{~g} / 100 \mathrm{~g}$ seed dosage or concentration had the highest potency of insecticidal properties, its effect was clearly observed on the mortality rate of the insect, oviposition deterrence, seed weight loss and damage and even its suppressive effects on the emergence of F1 progeny. From the mortality studies, the insect mortality increased with increasing application rate or dosage After 7 and 14 days of exposure, the efficacy of the chicken shell powder is very close to conventional insecticide, permethrin at dosage of $0.5,1.0$ and 2.0 in treated maize grain. 
Application of the eggshell powder achieved significant reductions in the microbial populace associated with the grains. Different doses of the eggshell powder attained comparable quality indices to the chemical pesticide Rambo.

Bacterial load ranged between $1.20-2.71 \times 10^{4} \mathrm{cfu} / \mathrm{g}$, with the EGS dose of $2.0 \mathrm{~g}$ presenting best quality $\left(1.20 \times 10^{4} \mathrm{cfu} / \mathrm{g}\right)$ below presented RAMBO quality of $1.78 \times 10^{4}$.

The presence of coliforms poses significant health risks. There was a steady reduction in the total coliforms as the dose of treatment increased with the $0.25 \mathrm{~g}$ and $2.0 \mathrm{~g}$ of EGS powder to $3.90 \times 10^{2}-2 . \times 10^{2} \mathrm{cfu} / \mathrm{g}$.

Table 2: Shows the microbiological analysis of the grains over the study period.

\begin{tabular}{lllll}
\hline & Bacteria & Total Coliform & Feacal Coliform & Fungi \\
\hline Control & $2.71 \times 10^{4 \mathrm{~d}}$ & $4.01 \times 10^{2 \mathrm{~d}}$ & $1.60 \times 10^{2 \mathrm{c}}$ & $1.41 \times 10^{4 \mathrm{a}}$ \\
0.25 & $2.21 \times 10^{4 \mathrm{c}}$ & $3.90 \times 10^{2 \mathrm{~cd}}$ & $1.01 \times 10^{2 \mathrm{~b}}$ & $1.28 \times 10^{4 \mathrm{a}}$ \\
0.5 & $1.91 \times 10^{4 \mathrm{bc}}$ & $3.67 \times 10^{2 \mathrm{~cd}}$ & $5.0 \times 10^{1 \mathrm{a}}$ & $1.23 \times 10^{4 \mathrm{a}}$ \\
1 & $1.53 \times 10^{4 \mathrm{ab}}$ & $3.44 \times 10^{2 \mathrm{bc}}$ & $3.8 \times 10^{1 \mathrm{a}}$ & $1.53 \times 10^{4 \mathrm{ab}}$ \\
2 & $1.20 \times 10^{4 \mathrm{a}}$ & $2.48 \times 10^{2 \mathrm{~b}}$ & $0.00 \pm 0.00^{\mathrm{a}}$ & $8.58 \times 10^{3 \mathrm{a}}$ \\
Rambo & $1.78 \times 10^{4 \mathrm{bc}}$ & $1.61 \times 10^{2 \mathrm{a}}$ & $1.39 \times 10^{2 \mathrm{bc}}$ & $1.14 \times 10^{4 \mathrm{a}}$ \\
Significant value & 0.00 & 0.00 & 0.00 & 0,763 \\
& & & & \\
\hline
\end{tabular}

Mean followed by the same letter in a column are not significantly different $(\mathrm{P}<0.05)$ from each other using new Duncan multiple range test.

There was a total elimination of fecal coliform contamination at the dose of $2.0 \mathrm{~g}$.

The applied chemical pesticide RAMBO ${ }^{\mathrm{TM}}$ was observed to have less anti fungi activity compared to the eggshell powder as the doses increased. No fecal contamination was seen in the initial sample, this could be as a result of the good handling and storage processes

The bacterial contaminant which had $1.5 \times 10^{4}$ and $3.7 \times 10^{4}$ is within the acceptable range of $10^{3} \times 10^{5}$ (ICMSF, 1986)

It was observed that as the dose of treatment increases the microbial load was lowered establishing the efficacy of animal waste as safe bio preservatives. The treatment serves as antagonizes to microbial activity.

\section{DISCUSSION}

From the result obtained in this research, it was observed that eggshell powder has considerable effect on the mortality of adult Sitophilus zeamais and microbial load. Mortality of adult insects increased as the period of exposure and dosage of the eggshell powder increases. Eggshell powder has been reported to inhibit locomotion of adult insects (Adedire 
et al., 2011; Ileke et al., 2013). The weevils were unable to move freely because of the powder and this might have affected mating activities and sexual communication (Ileke and Olotuah, 2012).

Reduction in progeny growth may be due to early mortality and partial or complete retardation of embryonic development (Dike and Mbah, 1992).

The effect of the powder on adult weevil emergence might be due to the poor egg-laying capacity of the weevil and physiological changes induced by the powder.

The chicken eggshell powder tested at various level showed different bioactivity against Sitophilus zeamais at $\mathrm{p}<0.05$ reduce longevity of adult insect on treated maize grains.

The effect of the eggshell powder on viability of treated grains showed that none of the dosage level of the treatment used adversely affected the viability of the maize grains when compared with the untreated control and positive control after one month of storage.

The physical abrasion of the epicuticle lipid layer of insect pest caused by eggshell powder and active components in eggshell powder might have been responsible for insecticidal activities (Nwaubani and Fasoranti 2008). Thapon and Bourgeois, (1994) stated that eggshell powder consist of $94 \%$ calcium carbonate, $1 \%$ phosphate, $1 \%$ magnesium carbonate and $4 \%$ organic substance. The bacterial contaminant is within the acceptable range of $10^{3} \times 10^{5}$ (ICMSF, 1986).

It was observed that as the dose of the treatment increases, the microbial load reduced establishing the efficacy of the chicken eggshell powder as a safe bio preservative. The treatment serves as antagonize to microbial activity.

\section{CONCLUSION}

This study establishes the insecticidal potency of chicken eggshell powder as a good maize protectant by killing the insects $S$. zeamais, controlling microbial population and still maintaining grain quality and ultimately extends the shelf life of stored maize grain. This means it can be used as substitute for synthetic chemical.

\section{Future Research}

There is an ongoing research to compare and contrast between the efficacy of chicken eggshell powder with other bioactive pesticides in the control of storage insects. 


\section{REFERENCES}

Adedire CO \& Akinkurolere RO, 2005. Bioactivity of some plant extracts on coleopterous pests of stored cereals and grain legumes in Nigeria. Zoo Res. 26, 243-249.

Adedire, C. O., Obembe, O. O., Akinkurolele, R. O. \& Oduleye, O. (2011). Response of Callosobruchus maculatus (Coleoptera: Chysomelidae: Bruchidae) to extracts of cashew kernels. Journal of Plant Diseases and Protection, 118(2), 75-79.

Association of Official Analytical Chemists (AOAC, 2000). Official Methods of Analysis. 17th Ed. American Association of Official Analytical Chemists, Inc., Washington

Basic Practical Microbiology. (2006). A Manual by Society for General Microbiology (SGM) ISBN: 0953683834.

Boxall, R. A. (2001). "Post-harvest losses to insects: A World Overview." International Bio deterioration and Biodegradation. Tropical Product Institute 48(1): 137-152, Elsevier Science Limited, London.

Dasbak, M.A., Echezona, B.C. \& Asiegbu, J. E. (2008). Post-harvest bruchid richness and residual activity of pirimaphos methyl on Callosobruchus maculatus $\mathrm{F}$. infested pigeon pea (cajanus cajan L. Mill sp.) in storage. African Journal of Biotechnology, 8(2):311315. Department of Crop Science, University of Nigeria.

Dike, M. C., \& Mbah, O. I. (1992). Evaluation of lemon grass (cydopogon citrate staph.) products in the control of Callusobruchus maculatus _ (F.) on stored cowpea. Nigerian Journal of Plant Protection 14: 88-91.

Gras, P.W., Kaur, S., Lewis, D.A., O'Riordan, B., Suter, D. A. I. \& Thomson, W.K.T., (2000). How and why to keep grain quality constant. 526-530. in: Cereals 2000 Proceedings 50th Australian Cereals Conference, 195-198. Royal Australian Chemistry Institute, Melbourne. Australia.

Ileke, K. D. \& Olotuah, O. F., (2012). Bioactivity of Anacardium occidentalis and Allium sativum powders and oils extract against cowpea bruchid, Callosobruchus maculatus (fab) (coleopteran: bruchidae). International Journal of Biological Science (1): 96-103.

Ileke, K. D., Bulus, D. S. \& Aladegoroye, A. Y. (2013). Effect of three medicinal plant products on survival, oviposition and progeny development of cowpea bruchid Callosobruchus maculatus (fab), [ coleopteran: chrysomelidae] infesting cowpea seeds in storage. Biological Sciences: 6 (1): 61-66.

International Commission on Microbiological Specification for Foods (ICMSF, 1986). Microorganisms in Foods 2. Sampling for microbiological analysis: Principles and specific applications. 1986. 2nd Ed. International Commission on Microbiological Specifications for Foods.

International Institute of Tropical Agriculture (IITA, 2003). Research Guide 30, IITA Training Program PMB 5320, Ibadan, Nigeria 2003. 43.

Kling, J.G. (2000). A parameterfor expressing the suitability of an environment for insect development. Journal of stored Products Research, 7:13-20

Larger, R. H. M. \& Hill, G.D., (2001). Agricultural Plants, Second Edition, Cambridge University Press, New York, USA. 387.

Longe, O. O. (2010). Investigations into fumigant toxicity of mixed formulations of commercially produced Eucalyptus oil and Eugenia aromatica dust to Sitophilus zeamais (Motschulsky). International Journal of Biological, 2(5): Aborney- Calavi, Republic of Benin. 2010. pp83-87. 
Lyon, F. (2000). Science Direct- World Development: II. Trust, Networks and Norms: The creation of social capital in agricultural economies in Ghana. Journal of Stored Products Research, 28(4) 663-681. Elsevier Science Ltd., England.

MacNeil, J. H. (2006). Method and apparatus for separating protein membrane and shell material in waste eggshells. In: patent, U.S. ed. The Penn State Research Foundation, US.

Niber, B. T. (1994). The Ability of Powders and Slurries from Ten Plant Species to Protect Stored Grain from attack by Prostephanus truncatus Horn: (Coleoptera: Bostrichidae) and Sitophilus oryzae L: (Coleoptera: Curculionidae). Journal of Stored Product Research 30: 297-301.

Nwaubani, S. I. \& Fasoranti, J. O. (2008). Efficacy of cow bone charcoal dust in the management of the maize weevil, Sitophilus zeamais Motsch.

[Coleoptera:Curculionidae], and the lesser grain borer Rhizopertha dominica Fab.[Coleoptera;Bostrichidae],infesting stored maize(Zea mays L.) grains. Nigerian Journal of Entomology, 25: 15-25.

Odeyemi, O. O., \& Daramola A. M. (2000). Storage practices in the tropics: Food storage and pest problems.First Edition, Dave Collins Publication, Nigeria, 2: 235

Odeyemi, O. O., Masika, P. \& Afolayan, A. J. (2008). Insecticidal activities of essential oil from the leaves of Mentha longifolia L. subsp. Capensis against Sitophilus Zeamais (Motschulsky) (Coleoptera: Curculionidae). Africa Journal of Entomology, 16(2): 220-225.

Ofuya,T.I., \& Longe O.O.(2009). Investigation into fumigant effect of Eugenia aromatic dust against Callosobruchus maculatus (Fabricius).International journalof Crop Science.1:44-49

Oni, M. O., \& Ileke, K. D. (2008). Fumigant toxicity of four botanical plant oils on survival egg laying and progeny development of the dried yam beetle Dinoderus porcellus (Coleoptera: bostrichidae) Ibadan. Journal of Agricultural Research 4(2): 31-36.

Rao, S. V. R., Raju, M. V. L. N., Panda, A. K., \& Reddy, M. R., (2006). Sunflower seed meal as a substitute for soybean meal in commercial broiler chicken diets. Br. Poult. Sci., 47 (5): 592-598

Thapon, J. L. \& Bourgeois, C.M. (1994). Lavousier Technique at Documentation, L'Oeuf et les ovoproducts, 1994.

Zar, J. H. (1984).Biostatical Analysis $2^{\text {nd }}$ ed., Prentice -Hall International,Englewood Cliffs, N.J. 